UNDERGROUND MINING ENGINEERING 35 (2019) 13-21 $\quad$ UDK 62

\title{
RELATION BETWEEN CRUSTAL STRESS AND THICKNESS OF EARTH'S CRUST
}

Slavko Torbica ${ }^{1}$ and Veljko Lapčević ${ }^{1}$,

\begin{abstract}
Available models for estimation of crustal stress consider the vertical stress component as weight of above laying rocks, while horizontal stress components are estimated as function of vertical component. Herein, it is assumed that horizontal stress is effect of strain formed at seismogenic depth and transferred to shallower depth of rock mass. Strain rate is different depending on thickness of the crust and is different in different locations. Using available data regarding the measured maximum horizontal stress and depth of Moho discontinuity trend between these is obtained. Trend shows that maximum horizontal stress is decreasing with the thickness of the Earth's crust and vice versa. Finally, expression that defines maximum horizontal stress from Moho depth and deformation modulus of rock mass is provided.
\end{abstract}

Keywords: Crustal stress; Moho discontinuity; Deformation modulus

\section{INTRODUCTION}

Crustal stress is one of dominant parameters that affect design of underground facilities such as tunnels, mines, radioactive waste storages, scientific laboratories etc. Stress field in rock mass is defined by three stress components namely vertical and minimum and maximum horizontal stresses. State of stress where all three components are equal in their intensity is known as lithostatic state of stress. Albert Heim (Heim, 1878) postulated the first of theories regarding the state of stress in rock mass where he stated that at deeper part of the rock mass lithostatic stress is present, and that intensity of the vertical stress component is equal to the weight of above laying $\operatorname{rocks}\left(\sigma_{v}=\sigma_{H}=\sigma_{h}=\gamma \cdot g \cdot z\right)$. With this in regard, with average density of rocks $\left(\gamma=2.7 \mathrm{~g} / \mathrm{cm}^{3}\right)$ vertical stress is increased with depth by $27 \mathrm{MPa} / \mathrm{km}$. However, it is known that lithostatic state of stress exists only under specific conditions, in materials with low shearing strength such as clays and salt deposits. For sedimentary rocks biaxial stress state is suggested ( $\left.\sigma_{H}=\sigma_{h}=\frac{v}{1-v} \cdot \sigma_{v}\right)(\operatorname{Karl} \&$ Richart Jr, 1952), but this model did not relate to measured stresses in many cases. Nowadays, it is common that horizontal stress is expressed as function of vertical stress using the proportion coefficient (Brown \& Hoek, 1978; Van

\footnotetext{
${ }^{1}$ University of Belgrade - Faculty of Mining and Geology
} Emails: torbica@rgf.bg.ac.rs; veljko.lapcevic@ @rgf.bg.ac.rs; 
Heerden \& others, 1976).It was confirmed that maximum horizontal stress is 1-3 times vertical stress in depth down to $300 \mathrm{~m}$, and around 1 times vertical stress in depths 3000$4000 \mathrm{~m}$. However, on greater depths ratio between maximum horizontal and vertical stress component is below 1 .

World stress map (WSM) (Zang, Stephansson, Heidbach, \& Janouschkowetz, 2012) is a project that provides extensive database about orientation of the maximum horizontal stress in Earth's crust. Estimation of stress directions is based on different focal mechanisms (Barth, Reinecker, \& Heidbach, 2008) or from borehole measurement data. This project provides great insight in stress orientation in many locations, however having in mind that those directions are mostly determined from focal mechanisms of active faults extrapolation of those results on wider areas is under question mark. This comes from the knowledge that stress field around faults and major discontinuities is different than in other parts of rock mass. WSM provided one major conclusion regarding the crustal stress which is that direction of maximum horizontal stress is subparallel with direction of movement of tectonic plates (Müller, et al., 1992; Richardson, 1992; Zoback \& Healy, 1992).

Herein, intension is to make sublimation of existing knowledge to provide new insight in this filed. Thickness of the Earth's crust is different in different locations which corresponds with the depth of Moho discontinuity. Using available data about stress measurements and Moho depths at those locations it is intended to provide relation between those parameters and to emphasize its importance for stress analysis prior design of major underground facilities.

\section{DEPENDENCE OF MAXIMUM HORIZONTAL STRESS ON THICKNESS OF EARTH'S CRUST}

This research is based on assumption that same forces are the cause of maximum horizontal stress in Earth's crust and the movement of tectonic plates. This assumption originates from observation that direction of maximum horizontal stress is subparallel with direction of tectonic plates movement (Müller, et al., 1992; Richardson, 1992; Zoback \& Healy, 1992). Resistance to deformation of Earth's crust is increasing with depth and its maximum is apparently reached at seismogenic depth. At this depth strain is developed proportionally to deformation modulus and intensity of maximum horizontal stress. This strain, developed in direction of maximum horizontal stress, remains constant up to the surface of Earth.

Measurements of crustal stress have shown that maximum horizontal stress equals to vertical stress component at approximately $3 \mathrm{~km}$ of depth, while at deeper parts of crust vertical stress is increasing faster than horizontal. Considering average increment of vertical stress of $27 \mathrm{MPa} / \mathrm{km}$, at depth of $3 \mathrm{~km}$ vertical and maximum horizontal stress 
components are equal in their intensity ( $\sigma_{v}=\sigma_{H} \approx 80 \mathrm{MPa}$ ). At this depth stress waves propagate at approximate velocity of $6 \mathrm{~km} / \mathrm{s}\left(V_{p} \approx 6 \mathrm{~km} / \mathrm{s}\right)$, and if Poisson's ratio ( $v=0.25)$ and average rock density $\left(\gamma=2.7 \mathrm{~g} / \mathrm{cm}^{3}\right)$ are assumed, estimated deformation modulus of rock mass at depth of $3 \mathrm{~km}$ can be calculated to $80 \mathrm{GPa}$ (Mavko, Mukerji, \& Dvorkin, 1998). With known values of maximum horizontal stress and eformation modulus it is possible to determine the strain that is developed in direction of maximum horizontal stress $\left(\varepsilon_{H}=\sigma_{H} / E_{m}=80 / 80000=0.001\right)$. According to this, it is possible to determine the intensity of maximum horizontal stress at any location by knowing the deformation modulus of rock mass at that location.

However, some field test showed that vertical and maximum horizontal stress are already equal at depths around $1 \mathrm{~km}$ with intensity around $27 \mathrm{MPa}$. At this depth jointing of the rock mass has minimal or no influence on deformation modulus of rock mass, which leads to conclusion that difference of $50 \mathrm{GPa}$ for deformation modulus is too large.

Therefore, this leads to conclusion that strain is not constant in all parts of the Earth's crust, but its value is larger in locations where crust is thinner since horizontal stress is larger.

Table 1 presents available data regarding the measured horizontal stress and Moho depth. This data is selection of deeper tests in order to eliminate the influence of rock mass jointing on stress measurements. Deformation modulus of rock is stress dependent and its value is increasing with depth due to larger normal forces that act on discontinuities. At certain depth, deformation modulus of rock mass will become close to the Young's modulus of monolith rock, and below this depth deformation modulus behaves as Young's modulus. This defines the depth limit. Assuming that strain is not being changed vertically to the surface, it is to be concluded that stress is dependent only on rock mass deformation modulus. Therefore, on depths below depth limit stress is changed according to the equation (Kulhawy, 1975):

$$
E_{m}=E_{i} \cdot \sigma_{H}^{\alpha}
$$

Where:

$\mathrm{E}_{\mathrm{m}}$ - rock mass deformation modulus

$\mathrm{E}_{\mathrm{i}}$ - Young's modulus of monolith rock

$\sigma_{\mathrm{H}}-$ lateral stress

$\alpha$ - exponent that depends on the rock type 
Exponent $\alpha$ has value between $0-0.36$ for different rock types. However, its average value is around 0.1 . Transforming equation (1) we obtain following expression:

$$
E_{m}=E_{i} \cdot(27 z)^{0.1}
$$

Based on equation (2) it is possible to normalize measured stress (Table 1) for the depth of $1 \mathrm{~km}$ in order to make this values comparable between each other.

Table 1 Measured maximum horizontal stress and its normalization to depth of $1 \mathrm{~km}$, Moho depth and location of tests

\begin{tabular}{|c|c|c|c|c|c|}
\hline $\mathrm{Z}(\mathrm{m})$ & $\sigma_{\mathrm{H}}(\mathrm{MPa})$ & $27 \cdot Z)^{0.1}$ & $\begin{array}{c}\sigma_{\mathrm{H}}(1000) \\
(\mathrm{MPa})\end{array}$ & $\begin{array}{c}\mathrm{Z}_{\text {moho }} \\
(\mathrm{km})\end{array}$ & Location \\
\hline 3398 & 108 & 0.66 & 71 & 30 & Cajon Pass (Zoback \& Healy, 1992) \\
\hline 2974 & 105 & 0.67 & 70 & 30 & Cajon Pass (Zoback \& Healy, 1992) \\
\hline 853 & 61.5 & 1.14 & 70.6 & 35 & Timmins, Canada (McGarr \& Gay, 1978) \\
\hline 732 & 72.6 & 1.22 & 88 & 35 & Timmins, Canada (McGarr \& Gay, 1978) \\
\hline 853 & 53.3 & 1.14 & 61.2 & 35 & Timmins, Canada (McGarr \& Gay, 1978) \\
\hline 1219 & 80.7 & 0.84 & 67.6 & 42 & Sudbury Basin, Canada (McGarr \& Gay, 1978) \\
\hline 2134 & 79.5 & 0.71 & 56.5 & 42 & Sudbury Basin, Canada (McGarr \& Gay, 1978) \\
\hline 1219 & 60.3 & 0.84 & 50.5 & 42 & Sudbury Basin, Canada (McGarr \& Gay, 1978) \\
\hline 6500 & $115(71)$ & 0.6 & 42 & 45 & $\begin{array}{l}\text { Gravberg (Stephansson, Savilahti, Bjarnason, \& others, } \\
\text { 1989) }\end{array}$ \\
\hline 785 & 33.8 & 1.19 & 40.3 & 50 & Henderson Mine, Colorado (Brown \& Hoek, 1978) \\
\hline 1131 & 40.7 & 0.88 & 35.9 & 50 & Henderson Mine, Colorado (Brown \& Hoek, 1978) \\
\hline 573 & 31.6 & 1.28 & 40.5 & 50 & Wawa, Ontario (Brown \& Hoek, 1978) \\
\hline 573 & 19.9 & 1.28 & 25.5 & 50 & Wawa, Ontario (Brown \& Hoek, 1978) \\
\hline 573 & 38.3 & 1.28 & 49 & 50 & Wawa, Ontario (Brown \& Hoek, 1978) \\
\hline 664 & 21.6 & 1.25 & 27 & 54 & Mount Isa Mine, Qld. (Brown \& Hoek, 1978) \\
\hline 1089 & 24.8 & 0.92 & 22.7 & 54 & Mount Isa Mine, Qld. (Brown \& Hoek, 1978) \\
\hline 1000 & 40 & 1 & 40 & 54 & Mount Isa Mine, Qld. (Brown \& Hoek, 1978) \\
\hline 3720 & 103.5 & 0.65 & 67 & 31 & Visund, Norway (Wiprut \& Zoback, 2000) \\
\hline 3560 & 87 & 0.65 & 57 & 31 & Visund, Norway (Wiprut \& Zoback, 2000) \\
\hline 2830 & 71.5 & 0.68 & 48.4 & 31 & Visund, Norway (Wiprut \& Zoback, 2000) \\
\hline 2850 & 70 & 0.68 & 47.6 & 31 & Visund, Norway (Wiprut \& Zoback, 2000) \\
\hline 920 & 53.1 & 1.08 & 57 & 32 & $\begin{array}{l}\text { Jiaodong Peninsula, China (Miao, Li, Tan, \& Ren, } \\
\text { 2012) }\end{array}$ \\
\hline 920 & 55.9 & 1.08 & 60.3 & 32 & $\begin{array}{l}\text { Jiaodong Peninsula, China (Miao, Li, Tan, \& Ren, } \\
\text { 2012) }\end{array}$ \\
\hline 920 & 50.2 & 1.08 & 54.2 & 32 & $\begin{array}{l}\text { Jiaodong Peninsula, China (Miao, Li, Tan, \& Ren, } \\
\text { 2012) }\end{array}$ \\
\hline 970 & 60.3 & 1.02 & 61.5 & 32 & $\begin{array}{l}\text { Jiaodong Peninsula, China (Miao, Li, Tan, \& Ren, } \\
\text { 2012) }\end{array}$ \\
\hline 970 & 57.9 & 1.02 & 59.1 & 32 & $\begin{array}{l}\text { Jiaodong Peninsula, China (Miao, Li, Tan, \& Ren, } \\
\text { 2012) }\end{array}$ \\
\hline 970 & 57.2 & 1.02 & 58.3 & 32 & $\begin{array}{l}\text { Jiaodong Peninsula, China (Miao, Li, Tan, \& Ren, } \\
\text { 2012) }\end{array}$ \\
\hline
\end{tabular}




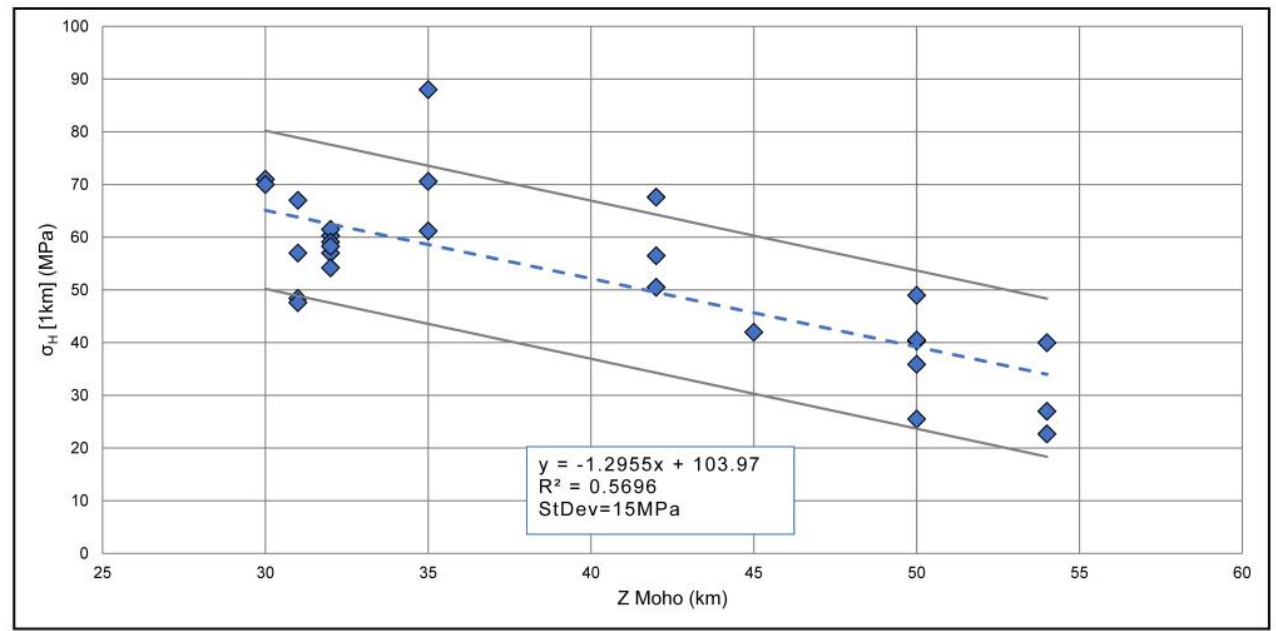

Figure 1 Change of maximum horizontal stress with the depth of Moho discontinuity

Plotting the stress data as function of depth of Moho discontinuity, dependence between these two is clear (Figure 1). Locations where Moho discontinuity is deeper, where Earth's crust is thicker, horizontal stress is smaller and vice versa. This also means that at locations where crust is thinner strain in direction of maximum horizontal stress (direction of tectonic plates movement) is larger and vice versa (Figure 2).

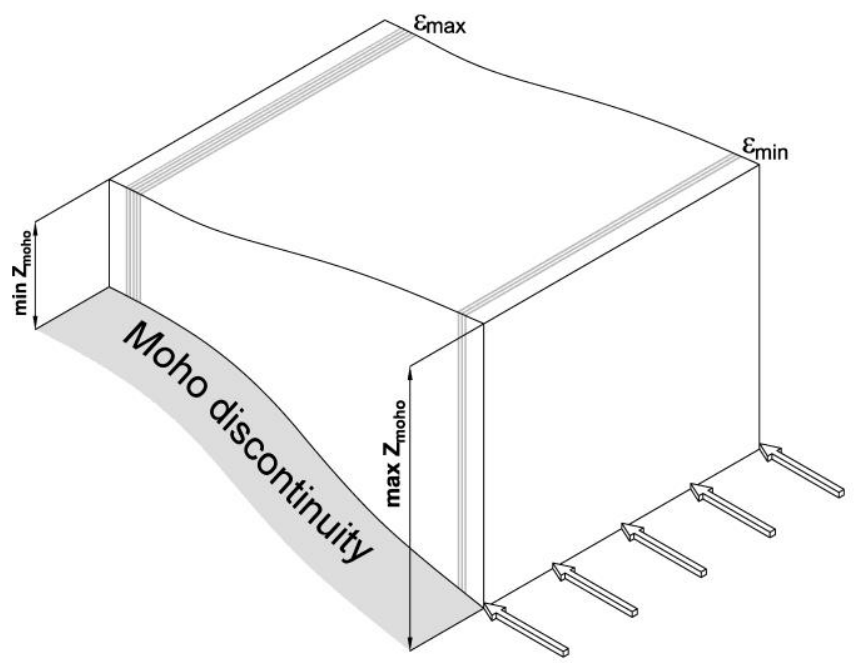

Figure 2 Strain change with thickness of Earth's crust 
Using the trendline from Figure 1 expression for maximum horizontal stress is obtained:

$$
\sigma_{H}=-1.2955 \cdot Z_{\text {Moho }}+103.97
$$

If we express the strain in direction of maximum horizontal stress as:

$$
\varepsilon_{H}=\frac{\sigma_{H}}{E}=-0.00001993 \cdot Z_{\text {Moho }}+0.00015995
$$

We obtain the expression for estimate of maximum horizontal stress using the depth of Moho discontinuity and deformation modulus of rock mass:

$$
\sigma_{H}[M P a]=E_{m}[G P a] \cdot\left(1.5995-0.01993 \cdot Z_{\text {Moho }}[k m]\right)
$$

\section{CONCLUSION}

Stress field of the Earth's crust has been investigated for long time and yet many problems remain unanswered. Common approach to relate the horizontal stress intensity with vertical stress doesn't provide much insight in the origins of the horizontal stresses and their magnitude estimation. Known facts are that stress is dependent on deformation modulus and vice versa, while maximum horizontal stresses are subparallel with movement direction of tectonic plates.

At seismogenic depth, strain in direction of maximum horizontal stress is formed and transferred to the shallower parts of the crust up to the surface. This strain influences the horizontal stress intensity in these parts of the rock mass proportionally with deformation modulus. Assumption that strain rate is constant up to the surface leads to conclusion that at shallower depths rock mass would have much higher deformation modulus than it is usual. Therefore, explanation would be that strain rate is different in different locations depending on the thickness of the crust or depth of Moho discontinuity.

Available data about measuring horizontal stress at depths over $500 \mathrm{~m}$ is collected and used for this research. Shallower measurements were not used since influence of rock mass jointing could affect the judgements of results. For these locations Moho depth is obtained and appended to the dataset. In order to have comparable results, stress intensity is normalized for the depth of $1000 \mathrm{~m}$ using relation provided by Kulhawy and which explains dependence of Young's modulus with lateral stress. Exponent value in equation (1) is taken with value 0.1 which is average value for different rock types. Plotting the 
normalized horizontal stress values as function of Moho depth provides clear trend that shows decrease of maximum horizontal stress with the increasing depth of Moho discontinuity. This trend is expressed with equation (3) and coefficient of determination for this expression is 0.56 .

Aforementioned implies that trend is obvious and lower value of determination coefficient has origins in several factors. Measured horizontal stress is reported without description of the rock mass. This is large uncertainty in this research since average (common) values are used to estimate deformation modulus of rock mass, parameter that has large influence on the stress intensity. Exponent in equation (2) has value 0.1, while its value for different rock types is between 0 and 0.36 . This means that for different location exponent will have different values and this could affect the results and decrease dispersity of results. Among these, Poisson's ratio and density of rocks provide some part of uncertainty in this research.

Presented research intended to provide new insight in the field of Earth's crustal stress by relating the intensity of maximum horizontal stress with the thickness of the crust. With all uncertainties that are incorporated in this research trend shows decreasing maximum horizontal stress intensity with increasing thickness of the crust and vice versa. 


\section{REFERENCES}

BARTH, A. et al. (2008). Stress derivation from earthquake focal mechanisms. World Stress Map Project Guidelines, 12.

BROWN, E. T., and HOEK, E. (1978). Trends in relationships between measured in-situ stresses and depth. International Journal of Rock Mechanics and Mining Sciences and Geomechanics Abstracts, 15, pp. 211-215.

HEIM, A. (1878). Untersuchungen über den Mechanismus der Gebirgsbildung: im Anschluss an die geologische Monographie der Tödi-Windgällen-Gruppe (Vol. 1). Schwabe.

KARL, T., and RICHART JR, F. E. (1952). Stresses in rock about cavities. Geotechnique, 3, pp.57-90.

KULHAWY, F. H. (1975). Stress deformation properties of rock and rock discontinuities. Engineering Geology, 9, pp.327-350.

MAVKO, G. et al. (1998). The rock physics handbook, 329 pp. Cambridge Univ. Press, New York.

MCGARR, A., and GAY, N. C. (1978). State of stress in the Earth's crust. Annual Review of Earth and Planetary Sciences, 6, pp.405-436.

MIAO, S. et al. (2012). Relation between the in-situ stress field and geological tectonics of a gold mine area in Jiaodong Peninsula, China. International Journal of Rock Mechanics and Mining Sciences, 51, pp.76-80.

MÜLLER, B. et al. (1992). Regional patterns of tectonic stress in Europe. Journal of Geophysical Research: Solid Earth, 97, pp.11783-11803.

RICHARDSON, R. M. (1992). Ridge forces, absolute plate motions, and the intraplate stress field. Journal of Geophysical Research: Solid Earth, 97, pp.11739-11748.

STEPHANSSON, O. et al. (1989). Rock mechanics of the deep borehole at Gravberg, Sweden. ISRM International Symposium.

VAN HEERDEN, W. L et al. (1976). Practical application of the CSIR triaxial strain cell for rock stress measurements. Investigation of Stress in Rock: Advances in Stress Measurement; Preprints of Papers, 1.

WIPRUT, D., and ZOBACK, M. (2000). Constraining the stress tensor in the Visund field, Norwegian North Sea: Application to wellbore stability and sand production. International Journal of Rock Mechanics and Mining Sciences, 37, pp.317-336.

ZANG, A. et al. (2012). World stress map database as a resource for rock mechanics and rock engineering. Geotechnical and Geological Engineering, 30, pp. 625-646. 
ZOBACK, M. D., and HEALY, J. H. (1992). In situ stress measurements to $3.5 \mathrm{~km}$ depth in the Cajon Pass scientific research borehole: Implications for the mechanics of crustal faulting. Journal of Geophysical Research: Solid Earth, 97, pp.5039-5057 